\title{
Assessment of Residence-Based Architectural Firms in South-West Nigeria: Users' Characteristics and Perceptions
}

\author{
Damilare Ifeoluwa Adebisi ${ }^{1},{ }^{*}$ Dorcas Oluwaseyi Adeoye ${ }^{1}$, Bolaji Samuel Oladimeji ${ }^{2}$, Olaitan Olutayo \\ Odunola $^{3}$ and Abosede Olubukola Akindele ${ }^{4}$ \\ 1. Department of Architecture, Ladoke Akintola University of Technology, Ogbomoso, Nigeria \\ 2. Department of Architecture, University of Ilorin, Ilorin Nigeria \\ 3. Department of Urban \& Regional Planning, Ladoke Akintola University of Technology, \\ Ogbomoso, Nigeria \\ 4. Department of Architecture, Caleb University, Imota, Lagos, Nigeria \\ *E-mail of the corresponding author: odadeoye@lautech.edu.ng);
}

\begin{abstract}
A residence-based architectural firm operates at the Principal Architect's house as it serves a dual purpose of being a place of residence and also a place of business. Most of the buildings used for this dual purpose fall short of the required facilities, thereby, making it difficult for effective discharge especially of architectural firm purpose. The study thus analysed users' perceptions on the available facilities for use to serve both the home and office in order to design facility for the home-office architectural practice. A cross-sectional survey design of both exploratory and descriptive approaches was employed for the study. A structured questionnaire focusing on housing and workplace characteristics was administered to 150 respondents. The data were analysed using frequency counts, cross tabulations, charts as well as content analysis. Findings from the study revealed that majority (62\%) operated out of private homes built exclusively for dwelling with $40 \%$ being detached bungalow house types with the highest room numbers, (47\%) being within 5 to 6 rooms, of these $47 \%$ served primarily as architectural firms. The staff strength was generally low (32\%) and were between 6-10 people with 44\% staffers working for 8 hours daily. While $57 \%$ of members of staff would prefer to stay for work overnight, $33 \%$ currently do not. Building features and neighborhood facilities are the main factors of satisfaction. The study also gathered that though the residential facilities available for use were good enough, they were not adequate for professional practice.
\end{abstract}

Keywords: architecture practices, accommodation, facilities, residence-based firms, users

DOI: $10.7176 / \mathrm{ADS} / 79-11$

Publication date: December $31^{\text {st }} 2019$

\section{Introduction}

A residence-based architectural firm is an architectural firm that operates at the Principal Architect's house. His house or private residence has either a space as an office or an office built separately on the same property. His house thus serves a dual purpose of being a place of residence and also a place of business howbeit separated as deemed fit by the Architect. Although the practice of architecture is rooted in classical antiquity, the name 'Architect' first came to be known in Italy during the Renaissance in the 15th and 16th centuries (Chauhan, 1994). The establishment of the practice of Architectural practice in Nigeria according to Arayela (2001) and Oladiti et al., (2017) is dated back to the founding of University College, Ibadan, in 1984 as an affiliate of London University and two British Architects Maxwell Frye and Jane Drew were commissioned to prepare the master plan and design the building. Chauhan, (1994) further noted that architectural practice evolved together with the society it served, first being defined as art, then science, and recently as the business of designing buildings. The practice of architecture in Nigeria has not been without challenges. Abdulkarim, (2002) noted that there had been economic fluctuations in the industry, which resulted in the cyclical nature of the industry. Sagada (2002) also stated that architectural services industry had also become increasingly competitive because of increase in the number of practices which contended for the few jobs, as well as the infringement of allied professions on the roles of the Architect. These challenges may have led to the changing nature of Nigerian architectural industry. With these challenges, many Architects decided to have their independent practices so as to cut down on costs, utility bills and expenses with many setting up their firms in their homes. Working from home has become more than a trend. Hard-working people over the world are trying to find the best way to accommodate creative and inspiring working environment in their homes (Teicu, 2014). The economy also contributed to making people adopt this contraption. Due to these residences not being purpose-built, several factors challenged their existence. Since the economy is the new reality, many Architects now face, their houses need to be evaluated to check how well it indeed meets 
the needs and functions of the occupants and where changes need to be effected. Thus, the study assessed users' satisfaction in residence-based architectural firms in South-West. The study evaluates the importance of users' satisfaction by providing information on how well the existing buildings serve the occupants. This encompasses architects who work in a residence-based architectural firms as they are the end users of this contraption and fully understand how it works or otherwise. The users are both principal and pupil architects. This study also seeks to find a balance between the home, office and staff interaction and while creating a private personal life for the architect, it also incorporates an effective working place that stimulates creativity, gives work satisfaction and fosters good relationships with clients and members of staff.Research questions considered were:

1. What are the perceptions of architects about a residence-based architectural firm?

2. Are the users (architects) satisfied with the facilities available in residence-based architectural firms?

3. What can be done to enhance architects' satisfaction with the existing facilities?

In the manufacturing sector today, human capital is still essential for most factories to carry out a variety of manual operations, in spite of the rapid advancement of automation technology and robotics. Futuristic vision of "unmanned manufacturing" (Deen 1993) is forbiddingly expensive, because all its hardware components need to be computer controlled so as to freely communicate with each other; and yet, most of the outcomes are not promising (Sun \& Venuvinod 2001). By and large, factories equipped with relatively simple machinery controls will require continuous attendance of human operators; for examples, textile mills, leather products, and medical appliances. With limited capital investments in production equipment, the main budget of their fixed costs lies on the workforce size (Techawiboonwong et al. 2006). With regard to cost-effectiveness, labour planning always opts for the minimum amount of workers needed to deal with the daily operations, as well as the probable rate of disturbance (Lim et al. 2008). The workforce disturbance is often ascribed to absenteeism and turnover, which may result in considerable loss of productivity for any labour-intensive division (Easton \& Goodale 2002). Buffering with redundant skilled workers (Molleman \& Slomp 1999) or relief workers (Redding 2004) might be a direct solution to absenteeism; however, the rising labour cost must be justifiable due to the fact that underutilisation of labour during low demand seasons is considered a waste of resources. Absenteeism is the measure of unplanned absences from workplace due to some reasons like personal emergency, accident, illness, etc. Turnover occurs when an active worker resigns from the company of his own accord, thus leaving a vacant post until a replacement is found. If such disturbance has caused a large number of tasks become unattended and overdue, the company is then vulnerable to overtime cost, shrunk capacity and productivity, extra queuing time, lost business income, etc. In order to prevent these deteriorative effects, optimising the number of workers can be helpful. As a fundamental branch of knowledge in manufacturing business, workforce management will never fall behind the times. Therefore, it is worth an attempt to incorporate a novel methodology, such as HMS, into the state of the art of workforce sizing.

\section{LITERATURE REVIEW}

The transition between work and private life is increasingly becoming blurred in terms of both time and location. From the perspective of holistic living, this development offers numerous advantages and a higher quality of life for many people who are more content when work mixes with family life. It also reduces travel time and one gains time when living and work activities overlap. An understanding of what the home and the office are is needed to fully understand how an effective merging between the two can take place.

\section{The Office or Workspace}

An office is a location, usually a building or portion of a building, where a company conducts its business (Businessdictionary.com, 2018). The architectural qualities of office spaces has been said to have a significant effect on comfort, satisfaction and efficiency. Such office buildings house the organizations they contain. According to (Elmahadi et al., 2011) two categories of analysis are established for office environments classification: the physical aspect and social aspects. These design aspects enable qualitative methods of investigation for analysis of the comparison. The physical aspect of office environment design is identified through the linkages between specific features of the physical environment and worker motivation, sense of well-being, job satisfaction and productivity. Researchers who have identified these correlations include Wineman (1986); Oldham (1988); Becker (1990); Carlopio and Garder (1992). In this study, the physical aspect looks at the comparison through architectural attributes such as space planning. The social aspect is identified in the use of shared spaces where the wider working environments are included providing a space for communication and 
chance encounters. Brill et al., (1985) found that spatial interaction can promote communication. Sunoo (2000) tried to integrate social properties with the architectural qualities to help them make sense of the space. In the study, the social aspect looks at the comparison through social interrelationships between spaces. The office space environments have not yet been looked at through the aspect of a house environment. The similarities between the quality of the office and the quality of the house and community can be found when the two types of architecture are compared. Studying both the house environment design qualities and the office design concept will allow a comparison between the house environment designs with the possibilities of a new office space environment design (Elmahadi et al., 2011).

\section{The Home Environment}

According to Fay (1999) the home is a hot house of ideas. In the house, we experiment with colour and texture, furnishings, lighting and room planning. But these are only a small part of the story. Often missing is the real opportunities to make the most of our living environment, to make it more comfortable, dynamic and inspiring. Living spaces however, should not only try to achieve a comfortable environment, but also try to challenge and adapt appropriate ways to dwell in space (Lockard, 2006). The house spaces do not only act as spaces to live in but also act as a society that reflects the cultural and civilization properties. For this reason, it is helpful to consider that house and comfortability has impact upon reflecting different design issues of the house or living environment (Elmahadi, et al., 2011). These design issues should indicate the architectural definition of the living environment. Martinez, (2007) remarks that the architectural definition of living environment begins at the position and relation of the spaces to each other (question of quantity) and reaches the design of the public, semi-public and private areas (question of quality). Herman (2005) refers to the story of the division of the hall-house that it gives clues to understanding how we make buildings adapt to the way we like to live. We enjoy open space, but still like to inhabit a mixture of private and social space. Fay (1999) commented about sources of inspiration for space studies, that the projects appear in three sections called adding space, re-inventing space and making space. He added that the first includes a variety of clever ideas for breaking through the boundaries of the existing space by adding extensions. Re-inventing space explores the ways in which Architects can reorder and reorganize the home to make the best use of existing space and so tailor the rooms to truly suit the needs. And making space delves into those underused and dead areas of the home and breathes new life into them. They provide a wealth of ideas and inspiration as well as show how to improve the physical and social qualities of the living space. However, the house environment design indicates some significant design issues such as the building volume, house and community as the basic architectural definition of living environment. Therefore, these design issues are helpful in achieving appropriate comfortability through forming the basic condition of human existence which indicates the definition of habitation.

\section{Factors Affecting Residential Satisfaction}

There are analysis of many variables that are strongly related to residential satisfaction and the occupiers' evaluations of the variables. Some of these are; building features such as number of bedrooms, size and location of spaces, quality of materials etc. and neighbourhood facilities (like proximity to schools, hospitals, shops, recreational facilities among others (Amaratunga and Baldry, 1998; Torbica and Stroh, 1999; Salleh, 2008). The study of Ukoha and Beamish (1997) indicated that residents in public housing in Abuja, Nigeria were satisfied with neighbourhood facilities such as closeness to schools, hospitals/clinics and shops/markets. They were however dissatisfied with their overall housing situation (structure types, building features, housing indications and housing management).

\section{Workspace Impact Elements}

According to a two-year workplace study by DYG Inc. for Knoll Inc., consisting of 1,500 interviews with 350 full-time office workers, it was discovered that people increasingly believe the workplace affects their productivity and job satisfaction. (DYG, Inc., 2001). The employees surveyed cited the following factors as having a "major" or "moderate" impact on their performance and satisfaction:

\section{Major Impact}

- Technology - providing the right technological tools and support to effective work.

- Storage space - supplying ample storage within close proximity to their desk.

- Climate control - allowing employees to control the workplace climate to provide comfort.

- Quiet space - minimizing noise that causes distractions and disruptions. 
- Adjustable and adaptable space - supplying space that can be personalized to fit an individual's work style.

\section{Moderate Impact}

These factors moderately affect their performance and satisfaction;

- Personal lighting control

- Ergonomic equipment and chairs for physical comfort

- Proximity to exterior windows, providing natural light and views

- Privacy and space for personal items at the workstation

- A visually appealing workplace with a professional atmosphere

The study also showed that satisfaction is crucial to staff retention. Employees planning to leave the organization were less satisfied with their physical workplace than those who planned to stay. When employees do not have control over their individual work environment (e.g. lighting, ergonomics, and quiet space), it negatively affects their physical health and mental disposition. These lead to increased absenteeism, employee dissatisfaction, inferior work products, and unsatisfactory customer service. (GSA, 2006). Such studies make clear that failing to provide space, systems, furniture, and technology that optimize occupants' performance can have detrimental longterm effects - reducing the organization's performance and increasing operational expenses. All things being equal, people will more often choose to work for organizations that provide better workplace accommodations.

\section{Other Office Forms}

There are several forms of offices which can be used for businesses based on the preference of the user. These include;

- A Home Office: A Home Office is an Office-like setup in the home of a self-employed person (businessdictionary.com, 2018). This is usually the easiest and cheapest way to start and operate a business. Mostly stores, garages or rooms in a residential building are used.

- The Virtual Office: A service that enables employees and business owners to work remotely by providing a range of business functions accessible through the internet. It enables organisations to create and maintain presence in a desirable location without the need to pay rent for an actual space (hubblehq.com, 2018).

- Co-working Spaces: Refers to space with a style of work that involves sharing of workspace, often an office and independent activity. Unlike in a typical office, those co-working are usually not employed by the same organization. Co-working offers a solution to problem of isolation many freelancers who work at home experience while at the same time letting them escape the distractions of home (hubblehq.com, 2018)

- Rental Offices: Spaces or units where a person or organisation can work operate or manufacture products and services. They are rented out on monthly basis and are mostly used by people just starting out or those checking to see if the location suits them (foundersguide.com, 2018).

- Leased Offices: This come with a fixed term of rent, usually six months, a year, five years contract with the landlord or company owning the unit. The contract in leased offices is more fixed and binding than rental offices (foundersguide.com, 2018).

\section{Communal Living and Work}

For an organization to perform exceptionally, it is important that the employees are comfortable with each other, share a good rapport and work in close coordination towards a common objective. When people see themselves as part of a larger body, they feel responsible and motivated to do good work and enjoy it rather than seeing it as a burden. Andrew (2017) noted that "It seems our sense of self-worth and well-being is inextricably linked to the feeling that we belong; that we are part of a group and a part of something greater than ourselves". He further opined that through sharing lives on a daily basis, we can also enjoy mutually supportive relationships that can be more trusting than usual. It has been observed that many employees spend most of their waking hours with co- workers than they do with their spouses and families. As such, it is important to allow employees the opportunity to build quality relationships with their co-workers. There are many benefits that can be reaped by small business owners who allow and foster good relationships in the workplace. These 
include; improved teamwork, improved employee morale, higher employee retention rates, increased productivity among others. Through sharing lives on a daily basis, we can also enjoy mutually supportive relationships that can be more trusting and more involving with socialising, work projects, sharing skills, meetings and celebrations. Living in a community of like-minded individuals is also a great place to learn- not just about oneself but also a whole range of skills and knowledge (Andrew, 2017). There are often people around with a wealth of experience and wisdom to share thus making it a safe place to make mistakes and grow in the process.

\section{Material and Methods}

\section{Study Area}

The study area was the six capital cities in South-West Nigeria as Figure 1 illustrated. The survey was carried out in the six capital cities in South-West Nigeria which include Ibadan, Ikeja, Abeokuta, Osogbo, Akure and AdoEkiti as the target study area. The cities were chosen based on the fact that the practice of Architecture as a profession mostly serves the elites of a society and as such those who are the-would-be clients of architects are based in the major cities of Nigeria. Thus, their offices were mostly located in the capital cities of any state in Nigeria.

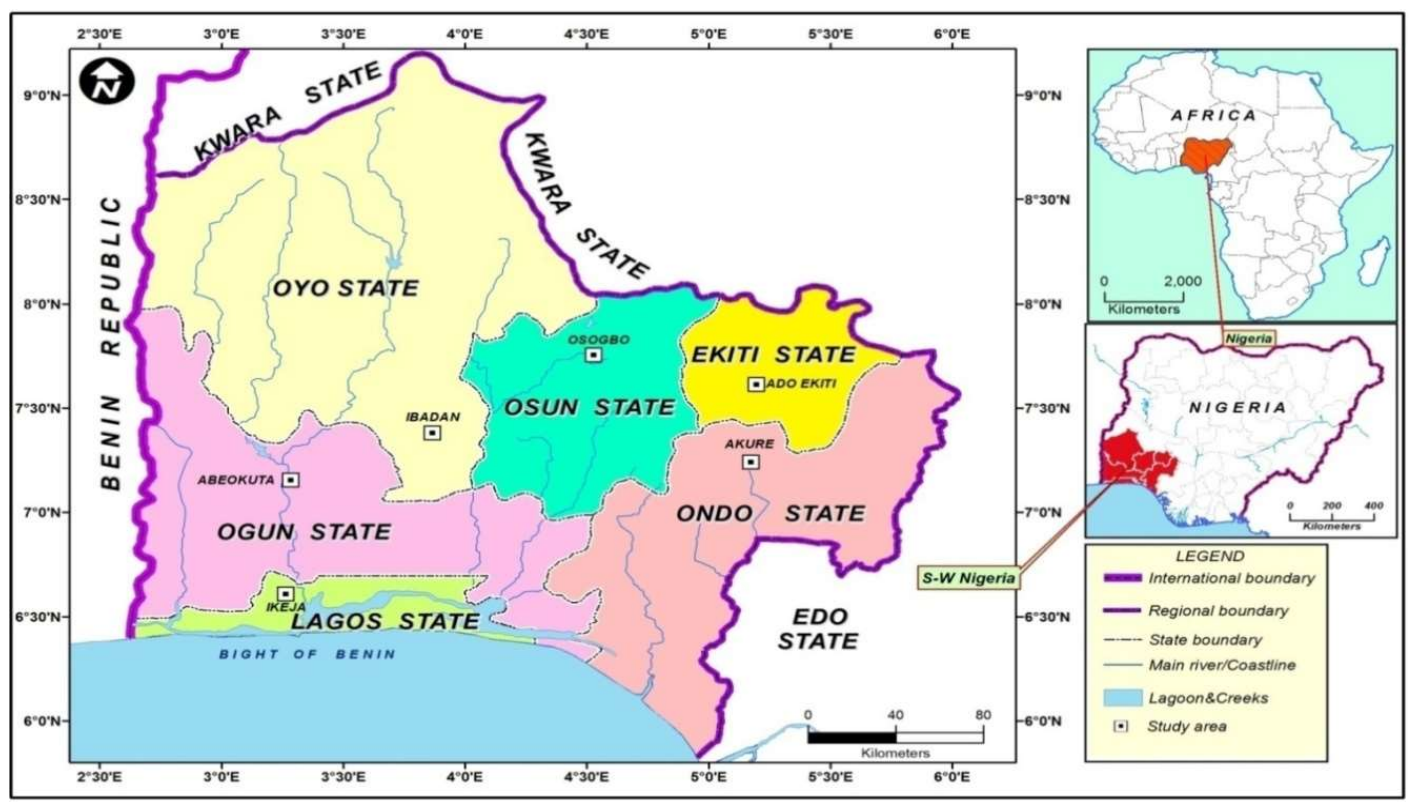

Figure 1: South Western Nigeria adapted from Ojo \& Saheed (2014)

\section{Research Design}

A cross-sectional survey type of design was employed which consists of exploratory, descriptive and explanatory designs to explain each of the many variables included in this study. Thus, this study was based on both qualitative and quantitative research designs. Structured questionnaire was adopted as instrument for quantitative research, while the qualitative research instrument relied on key information obtained from architects currently operating a residential architectural firm in Southwest Nigeria and the intending Architects working with them. According to the Architects Registration Council of Nigeria (ARCON, 2013), there are 329 registered architectural firms in Southwest Nigeria having about 40 percent of the total population of 4,744 registered architects in Nigeria (www.nia.ng, 2017).

\section{Types and Sources of Data}

Both primary and secondary data were used for the study. The primary data were obtained through questionnaires and were complemented with oral interviews of architects; (both principal and intending). The dataobtained from these sessions included; socio - economic characteristics of respondents, their work description, membership status of the Professional body, work hours per day; the level of their awareness about offices and residential firms, 
respondents' satisfaction level towards traditional office facilities, effect of the available facilities on the respondents, reason for non-satisfaction if there was any and benefits of residence-based firms as opposed to other firm types among other relevant questions.

\section{Sampling Technique}

A multi-stage sampling technique was adopted for this study. All capital cities of the South-West Nigeria were purposively selected because these cities are places where architecture is being practiced and as such the offices are also located to serve the elites of the society who are the would-be clients. These were six cities in all and include Ado Ekiti, Ikeja, Abeokuta, Akure, Osogbo and Ibadan. The next was to identify and enumerate Architects operating residential-architectural firms in these capital cities using the snow-ball approach; these were seventytwo (72) architects and lastly, all the residential-architectural firms totalling sixty-five (65) firms were sampled (as shown in Table 1).

\section{Sample Size}

A total of 65 residential-architectural firms with 150 architects were identified comprising at least one or two principal architect(s), an intending architect or more under their pupillage while others operated a solo practice (see Table 1).

Table 1: Distribution of Residential Architectural Firms and Categories of Architects in Southwest Nigeria

\begin{tabular}{|c|c|c|c|c|}
\hline & $\begin{array}{l}\text { Number } \\
\text { of } \\
\text { Firms }\end{array}$ & $\begin{array}{l}\text { Number } \\
\text { of } \\
\text { Principal } \\
\text { Architects }\end{array}$ & $\begin{array}{l}\text { Number } \\
\text { of } \\
\text { Intending } \\
\text { Architects }\end{array}$ & Total \\
\hline Ado-Ekiti & 7 & 7 & 8 & 15 \\
\hline Ikeja & 12 & 14 & 11 & 25 \\
\hline Abeokuta & 5 & 5 & - & 5 \\
\hline Akure & 19 & 22 & 28 & 50 \\
\hline Osogbo & 15 & 17 & 28 & 45 \\
\hline Ibadan & 7 & 7 & 3 & 10 \\
\hline Total & 65 & 72 & 78 & 150 \\
\hline
\end{tabular}

Source: Author's Compilation

\section{Method of Data Collection}

An array of methods was used to collect data. These included:

i) Use of interview technique: This is a direct face -to- face conversation between the interviewer and the respondent suited for small sample population with narrow geographical spread (Bernard, 2000). For this study, qualitative data was obtained from both practicing and intending Architects by means of in-depth interview. Questions to get information on office space satisfaction, work flow in the spaces; organizational spacing amidst others were asked.

ii) Administration of structured questionnaire: Leedy, (1997) opined that questionnaire is an instrument that can be used to observe data beyond the physical reach of the observer. In this study, quantitative data was collected through structured questionnaire technique, which was adopted in obtaining information from practicing and intending Architects. The questionnaire was designed to give an assessment of current workspace satisfaction and perception from the users' view point. The respondents were asked to indicate the level of satisfaction/dissatisfaction using some selected quality performance criteria on a 1 - 5 Likert-type scale.

\section{Method of Data Analysis}

The data obtained were imputed into Statistical Package for Social Scientists (SPSS) package for analyses. The data collected were analyzed using descriptive statistics. The results from the analysis were summarized and presented in tabular forms, pie chart and bar charts were used to summarise the data into means, percentages, frequencies distribution table, standard deviation among others. Also, results from the observation checklist used and interview granted were analysed using content analysis. The level of workspace satisfaction was measured by using a five-point Likert scale - "1" for very dissatisfied, "2" for dissatisfied, "3" for slightly satisfied, "4" for satisfied and "5" for very satisfied. In order to determine Users' satisfaction with the facilities available in the Residential Architectural Firms, respondents were provided with a combination of propositions and statements on 
their living satisfaction within the house as whole, the physical environment, the facilities available for use, sleeping facilities, tolerance with noise level generated and satisfaction with the design of office provided including the connection between the work place and the living quarters. In order to proffer answers to these questions, a Likert scale was adopted attaching the value 5 to "Strongly Satisfied", 4 to "Satisfied", 3 to "Neutral", 2 to "Not Satisfied" and 1 to "Not Satisfied at all". They were instructed to measure their level of satisfaction with each of the identified aspects.

To obtain Summation of Weighted Value (SWV), the product of the total numbers of responses to each variables and the weight attached to each ratings were summed up, i.e. $(a x 5)+(b x 4)+(c \times 3)+(d x 2)+(e x 1)$. The mean was also obtained by summing up the SWV and dividing it with the total number of variables $(\mathrm{n}=10)$. In other words; a mean value was attained by dividing the Satisfaction Weight Value (SWV) by the number of respondents (NR) and by dividing the products by number of facilities.

$\mathrm{NR}(\mathrm{f})=$ Number of Respondents or Summary of Frequency

SWV = Satisfaction Weight Value ( $\sum$ Rating)

$\mathrm{PFSI}=$ Perceived Facilities Satisfaction Index $(\mathrm{SWV} / \mathrm{NR})$

$\mathrm{N}=$ Total Number of Facilities

$\mathrm{X}=$ Average Mean $\left(\sum \mathrm{PFS} / \mathrm{N}\right)$ and $\mathrm{D}=$ Deviation $(\mathrm{PFSI}-\mathrm{X})$

\section{Results and Discussion}

The findings from the study depicted the socio-economic characteristics of respondents as shown Table 2.

\section{Sex of respondents}

Among 150 respondents; 105 (70\%) were males while 45 (30\%) were females (Table 2). When disaggregated by cities, the proportion remained similar across the cities as there were more males than females in all the sampled cities in Southwest Nigeria except for Ado-Ekiti. The proportion of male to female were; $(60 \%)$ in Ikeja, $(100 \%)$ in Abeokuta; (60\%) in Akure; (88.9\%) in Osogbo and (100\%) in Ibadan as against, $(40 \%)$ in Ikeja, $(0 \%)$ in Abeokuta; $(40 \%)$ in Akure; $(11 \%)$ in Osogbo and $(0 \%)$ in Ibadan respectively, however the ratio of females to males was higher and ranged between $67 \%$ to $33 \%$ in Ado-Ekiti. The prevalence of male respondents could be due to the fact that males find it easier to work and live in residential firms as compared to their female counterparts (Table 2). Another reason could be due to the fact that technical professions such as architecture are maledominated (Olurin, 2003).

\section{Age of respondents}

The age distribution of the respondents showed that majority (73\%) of the respondents were within 21 to 30 years, $20(13 \%)$ were below 20 years, $10(7 \%)$ were within 31 to 40 years and $10(7 \%)$ were within 41 to 50 years. This indicated that all respondents were very agile and active (Table 2).

\section{Marital status}

Six marital statuses of 'married,' 'widow,' 'divorced,' 'separated,' and 'single parents' were identified in the study area. However, single and married status alone was filled. Results from the study indicate that majority of the respondents $105(70 \%)$ were single (Table 2 ) while only $45(30 \%)$ were 'married'. When compared among the capital cities, single respondents were found to be more than married people; only Ado-Ekiti had a higher population of married respondents $(67 \%)$ to single respondents $(33 \%)$. The city with the highest number of single respondents was Akure with 35(70\%) respondents as against 15(30\%) married respondents. The prevalence of single respondents could be due to the fact that singles do not have marital responsibilities yet and as such can still live within the premises of their workplace (Table 2).

\section{Ethnicity of respondents}

The study established that majority of the respondents $135(90 \%)$ were Yoruba from South-western Nigeria. although some other categories of geographical spread of ethnicity in the country were represented; with the Igbos having 5(3\%) and other ethnic groups being 10(7\%) (Table 2). This could be because the study was carried out in the South-western region of Nigeria where there is prevalence of the Yoruba people.

\section{Religion of Respondents}

Information obtained on religion affiliation of respondents showed that 105 respondents (70\%) were Christians while 45 respondents $(30 \%)$ were Muslims. This finding confirmed the predominance of the Christian and 
Islamic religions in Nigeria (See table 2).

Table 2: Socio-Economic Characteristics, Membership Status and Work description of Respondents

\begin{tabular}{|c|c|c|c|c|c|c|c|c|c|c|c|c|c|c|c|}
\hline \multirow{3}{*}{$\begin{array}{l}\text { Socio-economic } \\
\text { Characteristics }\end{array}$} & & \multicolumn{12}{|c|}{ State Capital } & \multirow{2}{*}{\multicolumn{2}{|c|}{ Total }} \\
\hline & & \multicolumn{2}{|c|}{ Ado-Ekiti } & \multicolumn{2}{|l|}{ Ikeja } & \multicolumn{2}{|c|}{ Abeokuta } & \multicolumn{2}{|c|}{ Akure } & \multicolumn{2}{|c|}{ Osogbo } & \multicolumn{2}{|c|}{ Ibadan } & & \\
\hline & & Freq & $\%$ & Freq & $\%$ & Freq & $\%$ & Freq & $\%$ & Freq & $\%$ & Freq & $\%$ & Freq & $\%$ \\
\hline \multirow[t]{3}{*}{ Sex } & Male & 5 & 33 & 15 & 60 & 5 & 100 & 30 & 60 & 40 & 89 & 10 & 100 & 105 & 70 \\
\hline & Female & 10 & 67 & 10 & 40 & 0 & 0 & 20 & 40 & 5 & 11 & 0 & 0 & 45 & 30 \\
\hline & Total & 15 & 100 & 25 & 100 & 5 & 100 & 50 & 100 & 45 & 100 & 10 & 100 & 150 & 100 \\
\hline \multirow[t]{5}{*}{ Age } & $<20$ & 0 & 0 & 0 & 0 & 0 & 0 & 10 & 20 & 10 & 22 & 0 & 0 & 20 & 13 \\
\hline & $21-30$ & 10 & 67 & 25 & 100 & 5 & 100 & 35 & 70 & 25 & 56 & 10 & 100 & 110 & 73 \\
\hline & $31-40$ & 5 & 33 & 0 & 0 & 0 & 0 & 0 & 0 & 5 & 11 & 0 & 0 & 10 & 7 \\
\hline & $41-50$ & 0 & 0 & 0 & 0 & 0 & 0 & 5 & 10 & 5 & 11 & 0 & 0 & 10 & 7 \\
\hline & Total & 15 & 100 & 25 & 0 & 5 & 100 & 50 & 100 & 45 & 100 & 10 & 100 & 150 & 100 \\
\hline \multirow[t]{3}{*}{ Marital Status } & Single & 5 & 33 & 20 & 80 & 5 & 100 & 35 & 70 & 30 & 67 & 10 & 100 & 105 & 70 \\
\hline & Married & 10 & 67 & 5 & 20 & 0 & 0 & 15 & 30 & 15 & 33 & 0 & 0 & 45 & 30 \\
\hline & Total & 15 & 100 & 25 & 100 & 5 & 100 & 50 & 100 & 45 & 100 & 10 & 100 & 150 & 100 \\
\hline \multirow[t]{4}{*}{ Ethnicity } & Yoruba & 15 & 100 & 15 & 60 & 5 & 50 & 45 & 100 & 45 & 100 & 10 & 100 & 135 & 90 \\
\hline & Igbo & 0 & 0 & 5 & 20 & 0 & 0 & 0 & 0 & 0 & 0 & 0 & 0 & 5 & 3 \\
\hline & Others & 0 & 0 & 5 & 20 & 5 & 50 & 0 & 0 & 0 & 0 & 0 & 0 & 10 & 7 \\
\hline & Total & 15 & 100 & 25 & 100 & 10 & 100 & 45 & 100 & 45 & 100 & 10 & 100 & 150 & 100 \\
\hline \multirow[t]{4}{*}{ Religion } & Christian & 10 & 67 & 25 & 100 & 0 & 0 & 30 & 60 & 35 & 78 & 5 & 50 & 105 & 70 \\
\hline & Islam & 5 & 33 & 0 & 0 & 5 & 100 & 20 & 40 & 10 & 22 & 5 & 50 & 45 & 30 \\
\hline & Others & 0 & 0 & 0 & 0 & 0 & 0 & 0 & 0 & 0 & 0 & 0 & 0 & 0 & 0 \\
\hline & Total & 15 & 100 & 25 & 100 & 5 & 100 & 50 & 100 & 45 & 100 & 10 & 100 & 150 & 100 \\
\hline \multirow{5}{*}{ Educational Status } & OND/HND & 0 & 0 & 5 & 20 & 0 & 0 & 10 & 20 & 10 & 22 & 5 & 50 & 30 & 20 \\
\hline & B.sc/B. Tech & 10 & 67 & 5 & 20 & 0 & 0 & 5 & 10 & 20 & 45 & 0 & 0 & 40 & 27 \\
\hline & M.sc/M. Tech & 5 & 33 & 15 & 60 & 5 & 100 & 35 & 70 & 15 & 33 & 5 & 50 & 80 & 53 \\
\hline & Ph.D. & 0 & 0 & 0 & 0 & 0 & 0 & 0 & 0 & 0 & 0 & 0 & 0 & 0 & 0 \\
\hline & Total & 15 & 100 & 25 & 100 & 5 & 100 & 50 & 100 & 45 & 100 & 10 & 100 & 150 & 100 \\
\hline \multirow[t]{5}{*}{ Work description } & Intern & 0 & 0 & 0 & 0 & 0 & 0 & 0 & 0 & 5 & 12.5 & 0 & 0 & 5 & 100 \\
\hline & Technologist & 0 & 0 & 0 & 0 & 0 & 0 & 10 & 20 & 5 & 12.5 & 5 & 33 & 20 & 100 \\
\hline & Interior designer & 0 & 0 & 0 & 0 & 0 & 0 & 0 & 0 & 0 & 0 & 5 & 33 & 5 & 100 \\
\hline & Architect & 15 & 100 & 25 & 100 & 5 & 100 & 40 & 80 & 30 & 75 & 5 & 33 & 120 & 100 \\
\hline & Total & 15 & 100 & 25 & 100 & 5 & 100 & 50 & 100 & 40 & 100 & 15 & 100 & 150 & 100 \\
\hline \multirow{7}{*}{$\begin{array}{ll}\text { NIA } & \text { Membership } \\
\text { Status } & \end{array}$} & Student & 5 & 33 & 5 & 14 & 0 & 0 & 25 & 56 & 10 & 25 & 10 & 100 & 55 & 37 \\
\hline & Technologist & 0 & 0 & 0 & 0 & 0 & 0 & 0 & 0 & 0 & 0 & 0 & 0 & 0 & 0 \\
\hline & $\begin{array}{l}\text { Graduate } \\
\text { Member }\end{array}$ & 10 & 67 & 5 & 14 & 0 & 0 & 5 & 11 & 0 & 0 & 0 & 0 & 20 & 13 \\
\hline & $\begin{array}{l}\text { Associate } \\
\text { Member }\end{array}$ & 0 & 0 & 20 & 58 & 5 & 100 & 15 & 33 & 25 & 63 & 0 & 0 & 65 & 43 \\
\hline & Full Member & 0 & 0 & 5 & 14 & 0 & 0 & 0 & 0 & 5 & 12 & 0 & 0 & 10 & 7 \\
\hline & Fellow & 0 & 0 & 0 & 0 & 0 & 0 & 0 & 0 & 0 & 0 & 0 & 0 & 0 & 0 \\
\hline & Total & 15 & 100 & 35 & 100 & 5 & 100 & 45 & 100 & 40 & 100 & 10 & 100 & 150 & 100 \\
\hline \multirow{8}{*}{$\begin{array}{l}\text { Average monthly } \\
\text { salary }\end{array}$} & $<\# 18000$ & 5 & 33 & 0 & 0 & 0 & 0 & 15 & 100 & 5 & 100 & 5 & 100 & 30 & 100 \\
\hline & $\begin{array}{l}\# 18001- \\
\$ 30000\end{array}$ & 0 & 0 & 5 & 100 & 0 & 0 & 10 & 100 & 5 & 100 & 10 & 100 & 30 & 100 \\
\hline & $\begin{array}{l}\text { \#30001- } \\
\$ 50000\end{array}$ & 0 & 0 & 5 & 100 & 0 & 0 & 0 & 0 & 10 & 100 & 15 & 100 & 45 & 100 \\
\hline & $\begin{array}{l}\text { \#50001- } \\
\# 100000\end{array}$ & 5 & 33 & 0 & 0 & 5 & 100 & 5 & 100 & 0 & 0 & 0 & 0 & 15 & 100 \\
\hline & $\begin{array}{l}\$ 100001- \\
\$ 150000\end{array}$ & 0 & 0 & 10 & 100 & 0 & 0 & 0 & 0 & 10 & 100 & 0 & 0 & 10 & 100 \\
\hline & $\begin{array}{l}\# 150001- \\
\$ 200000\end{array}$ & 5 & 33 & 5 & 100 & 0 & 0 & 0 & 0 & 0 & 0 & 0 & 0 & 10 & 100 \\
\hline & $>\$ 200001$ & 0 & 0 & 5 & 100 & 0 & 0 & 0 & 0 & 0 & 0 & 0 & 0 & 5 & 100 \\
\hline & Total & 15 & 100 & 30 & 100 & 5 & 100 & 40 & 100 & 30 & 100 & 30 & 100 & 145 & 100 \\
\hline
\end{tabular}

Source: Authors Compilation 


\section{Educational status}

The study established that majority of the respondents 80 of the total respondents (53\%) had either Masters of Science or Masters of Technology (M.Sc. or M. Tech) in Architecture. This is followed by 40 (27\%) of the total who had either Bachelor of Science or Bachelor of Technology (B. Sc. or B. Tech), while 30(20\%) had Higher National Diploma (H.N.D) as their educational qualification (Table 2). It could be deduced that most of the respondents were Masters Degree holders and this could be due to the fact that part of Architects Registration Council of Nigeria (ARCON) directive for registration is the acquiring of at least a Masters degree in Architecture as a prerequisite for sitting for the final professional examinations.

\section{Work Description of Respondents}

The study showed that majority of the respondents $120(80 \%)$ were Architects, $20(14 \%)$ were technologists, $5(3 \%)$ were interns, while the rest $5(3 \%)$ work as interior designers. This also supports the fact that most respondents were Architecture graduates who must have finished from a Nigerian University where Architecture is being offered as a course of study (See Table 2).

\section{Professional Membership Status of Respondents}

It was established according to the study that majority of the respondents 65(43\%) were Associate members, 55 (37\%) were students members, $20(13 \%)$ were graduate members, while 10 (7\%) were full members. Associate members were the most involved in the study followed by student members. The prevalence of associate members shows that the respondents were the most populous practicing from different residence-based firm. Again, these categories of members were the intending architects who need the two years compulsory tutelage as stipulated by Architects Registration Council of Nigeria (ARCON). This also implies that majority of the practicing architects in the market are not fully registered which is a pointer to the fact that there are few registered architects in Nigeria as at today.

\section{Salary Distribution of Respondent}

Out of the total respondents, 30 representing $20 \%$ had income below $\$ 18000,30$ representing $20 \%$ had income between $\$ 18001$ - $\$ 30000,30$ representing $20 \%$ had income between $\$ 30001$ - $\$ 50000,25$ representing $17 \%$ had income between $\$ 50001$ - $\$ 100000,20$ representing 13\% had income between $\$ 100001$ - $\$ 150000,10$ representing 7\% had income between $\$ 150001$ - $\$ 200,000$ and 5 representing 3\% of the respondents had income of $\$ 200001$ and above. It shows that majority of the respondents earn between $\$ 18001-\$ 50000$ (\$40-\$111).

\section{Ratio of Single to Married People}

The study established that 10 representing $11.1 \%$ of the company had one single staff to one married staff, 30 representing $33.3 \%$ of the company had for every two single staff one married staff, 35 representing $38.9 \%$ of the company had for every three single staff one married staff, 10 representing $11.1 \%$ of the company had for every four single staff one married staff and $5(5.6 \%)$ of the companies had for every three single staff two married staff (Figure 2).



Ratio $1: 1-11 \%$

Ratio 2 : 1 - 33\%

Ratio $3: 1$ - 39\%

Ratio 4 : 1 - 11\%

Ratio 3 : 2 - 6\%

Figure 2: Ratio of Single to Married People, Source: Authors Compilation 
This implies that the number of single staff was greater than those of married staff as majority of the respondents were associate members who were fresh master's holders from their respective institutions and were yet to be married.

\section{Working Hours per Day}

Figure 3 also revealed that out of the total respondents, majority $65(44 \%)$ of the respondents worked for 8 hours a day, $35(23 \%)$ worked for 7 hours a day, 20 (13\%) worked for 10 hours and above while $10(7 \%)$ worked for 9 hours a day (Figure 3). Thus from this, majority of the respondents spend between 7-8 hours a day at their work place. This is observed as some of the respondents are not living within the premises of their workplace and thus need to travel back home to spend the rest of the day. A typical illustration of this routine adventure was as reflected by the response of a 32years old married lady under pupillage during the interview session:

"I am a 32years married lady with three kids aged between 2, 4 and 6. I resume work here between 8:30 am - 9:00 am amidst the traffic jam and other associated transport problems. I spend close to 7-8 hours daily at work and leave around 5:00 pm daily in order to catch up with other house chores and family obligations at home. I don't have a helper at home and my hubby who used to help the kids from crèche and school had just been transferred from this town to another branch of his company in another town. It has not been so easy to combine these tasks coupled with my distance from home to work place every day of the week. I would like to operate a residential-home office firm by the time I am fully registered and start my own firm."

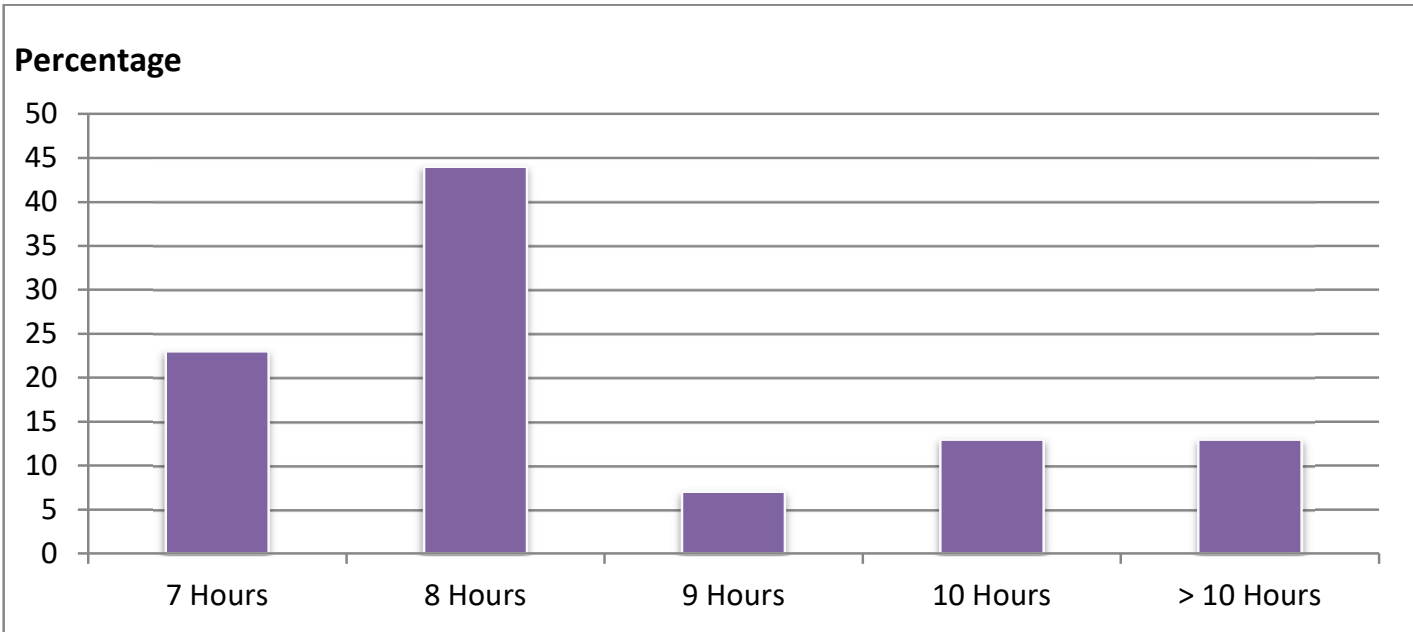

Figure 3: Working Hours per Day, Source: Authors Compilation

Another interesting scenario was captured during the interview session with one of the Architects under tutelage:

"I really like staying within the office premises. You know after the day's work; our principal used to work at night. This is the time I learn a lot from him!

You know he's such a busy man during the day for he goes from one site inspection to the another site meeting or meeting government officials who are our clients at their respective offices or even going for one approval process or the other. Some of us remain here during the day to battle with one design brief or design as assigned by him. But you know what? It is during this night hours he comes around to check and correct our daily work and comment on them. I gain more experience from him than my other colleagues who live outside here because

I'm privileged to stay with him as he takes his time to explain more of the Architectural rudiments of the profession to me. I am indeed blessed by this arrangement of residence-office thing." 


\section{Users' satisfaction with Facilities available in Residential Architectural Firms}

Table 3 shows the respondents' level of satisfaction Index (PFSI) with the facilities provided. The analysis of the responses evolved into an index called Respondent's Perceived Facilities Satisfaction Index (PFSI) which reflected their level of satisfaction with the design and facilities within this working-living environment.

From Table 3 it could be seen that the respondents were not satisfied with the sleeping facilities in the building (PFSI=3.13) which prompted this research activity; that is to redesign the residential- based architectural firms since most of the buildings used for this purpose were converted building and not purpose-built. This is followed by the proposition that the whole house as whole does not satisfy the users (PFSI=3.37), the studio/design space (PFSI=3.60) and lastly the distance between the Residents' Architects living area and the work area is not good enough $(\mathrm{PFSI}=3.57)$ as against the mean PFSI value of 3.63. However, those propositions that were positive and above the mean PFSI (3.63) include: the noise level generated in and around the building (PFSI=3.87), the office space provided $(\mathrm{PFSI}=3.83$ ); the facilities available for use $(\mathrm{PFSI}=3.77)$; the connections between working area and living quarters (PFSI=3.70); and lastly the office space provided (PFSI=3.63).

A mean value greater than 3.63 indicated that respondents are satisfied with such facility; in contrast, any mean value less than 3.63 indicates dissatisfaction to such facility. Table 4 summarizes the perceived facilities satisfaction index of respondents with the highest PFSI being 3.87 which is for the physical environment and the noise level being generated in and around the building and the lowest PFSI is 3.13 which is the satisfaction level for sleeping facilities.

A typical illustration of how dissatisfied the users (Respondents) are to the facilities provided was justified by a 27 years old male respondent as stated below:

"The rooms for sleeping were too small. Even one the room used by one of us was a lobby converted to bedroom. Though, each of us has separate rooms to ourselves for privacy reasons, the conveniences' are still being shared. The kitchen is nothing to write home about as it is too small. A time some clients come through the kitchen side because of its location and for the fact that the main entrance to the office reception could not be identified as approach to the office. Some of them even go to the principal Architect's quarters/residence directly. This has caused a lot of infringement into our private lives and that of our Principal's. I'd wished these facilities to be re-designed so as to have a clear Zoning between the work-area and the private quarters for the workers and my employer. I can't even entertain visitors because there is no facility like common room/ sitting/relaxation area to receive visitors or interact with other colleagues after the day's work. We are either remaining indoor in our rooms or stay under a shady-tree to gist, interact or receive our visitors. The whole facility needs total overhauling by re-designing and re-allocating some functional spaces by proper zoning."

Table 3: Perceived Facilities Satisfaction Index of Respondents

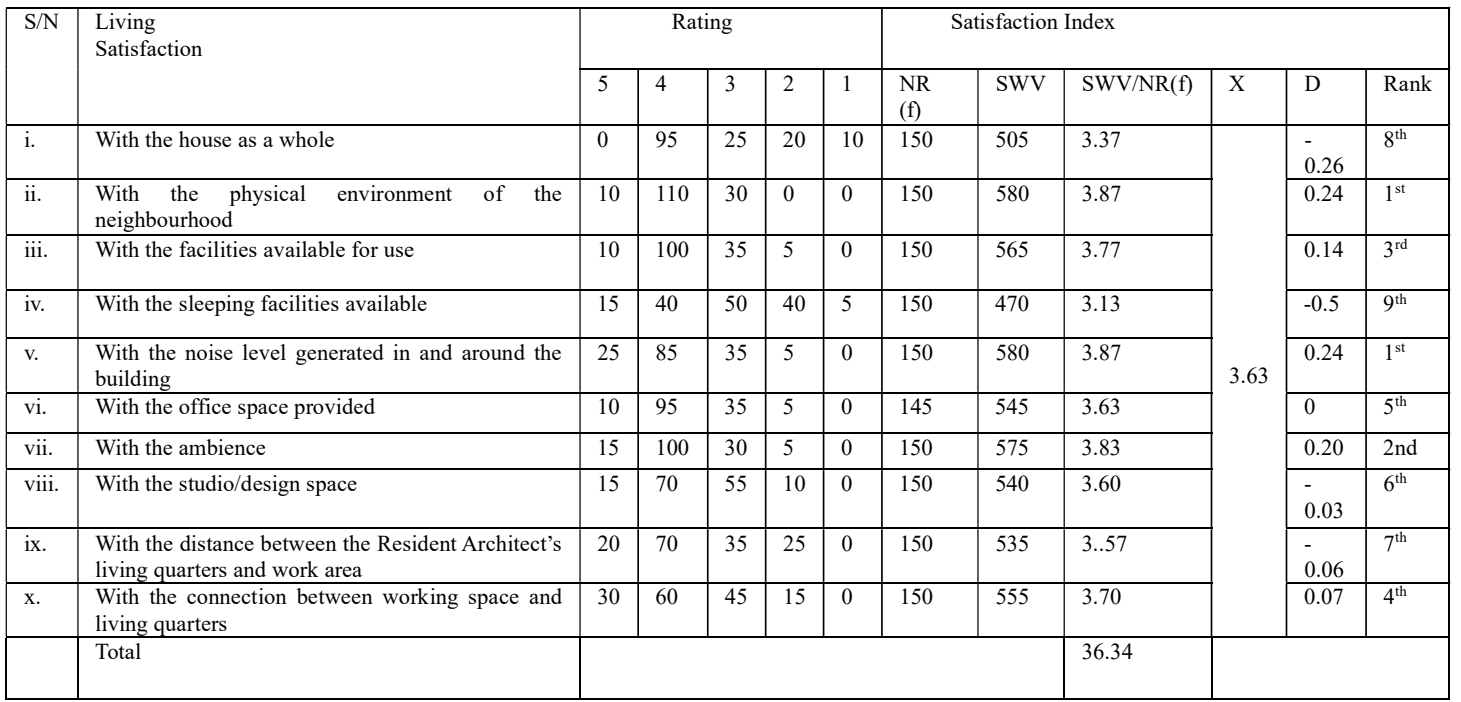

Source: Authors Compilation. 


\section{Summary of Findings}

This study seeks to examine residential-based architectural firms, their operations uniqueness of their relationship between the users and how the situations can improve. The study highlighted issues bordering on Architects under tutelage in residential architectural firms. The study reveals that the socio-economic characteristics related to the Architects qualification, their work description, membership status of the professional body(Nigerian Institute of Architects-NIA), their monthly earnings, and the ratio of single to married in the architectural firms selected among others. It also analyses the work hours of respondents per day. The main aim is to analyse their perception on selected variables that the respondents (users) felt satisfy that in their respective home-based Architectural firms and also identify those that are not satisfactory in order to improve on such for effective home-office and staff interaction. It also tried to seek how to find balance within these residential-based Architectural firms in order to incorporate an effective working place that can stimulate creativity, give work satisfaction and foster good interpersonal relationship amongst the Principal Partner(s) the intending Architects (those under tutelage and aiming to seat for their professional examinations in order to be fully professionally qualified and be registerable and the clients.

The study reveals that there were more males than females working in residential-based architectural firms due to the fact that Architecture as a technical profession is more populated by males than females confirming Olurin (2003). In the same vein, males find it easier to stay, work and live within the residential firms compared to their female counterparts as many of the males who are yet to marry do not have marital responsibilities and as such can still live within the premises of their working place. The problems facing the intending Architects range from accommodation problems to poor remunerations among others. This confirms the findings of Wasiri and Osunkunle (2010) that part of the problems faced by young Architects who undergo pupilage is accommodation problem. This is more prominent for those that leave their residences to seek employment in other towns or states while some Architects provide accommodation for these intending Architects and deduct from their monthly remunerations. This shows that most of these categories of Architects have to work in the home-office environment of their principals. Thus, the principal Architect needs to operate and manage his practice, clients and the intending Architect(s) all in his home of residence.

The study shows that while the facilities primarily available for the houses are satisfactory, those relating to the office in the houses are not adequate. This is due to the fact that most of the offices were not purpose built; they are either reused or converted spaces in the house or added afterthoughts. As such, they don't effectively cater for the needs of the users of the space. This study however, contributes to the discourse on the need to integrate the home-office concept in the new trend of professional practices in order to safe cost and overcome transportation and its associated problems that is usually experienced between the home and office. It advocates the need for an effective working place for the intending Architects, the principal, his home-office and effective interaction with the clients. Based on the findings and analyses, there is need to have a clear distinction between working and living areas, but the boundaries separating them can be more or less permeable, depending on the family situation. Zoning of the office as an entity separate from the private residence of the principal creates privacy for both the Principal with his family and the intending Architects. Zoning does several things as it separates family members from the client and customers in client-centered home-office. Boundaries within the home help establish work territories where interruptions and intrusions are more effectively controlled. Also, private work territories where the boundaries are largely symbolic can motivate and energies the users. However, this set up underscores professional identities and responsibilities in that most of these offices were not purpose-built and thus posed a lot of problems ranging from meeting clients at informal settings, inadequate space allocation of functional spaces and work-life encroaching on private lives because of nuclear dermarcat5ion amidst others. This corroborates the issue raised by Thompson et.al. (2004) that all organizations are confronted with trends and new developments that gradually and speedily produce changes important enough to acquire strategic responses from participating firms. The study noted that there is need to redesign and relocate and improve the sleeping facilities available in the home-offices while the distances between the Principal Architect's living quarters and working area should be properly zoned and separated. Thus, proper zoning of the work space and the living quarters should be addressed.

\section{Conclusion}

This study analysed users' satisfaction with facilities in residential-based-architectural firms in South-west Nigeria and seeks to find the balance between home, office and staff interaction by fusing a private personal life for the Principal Architect and incorporating an effective working conditions of the users..It reveals that there is need for 
good relationship between the employer, the clients and member of staff. Thus, good and effective relationships in a workplace foster teamwork improve employee morale, higher employee retention rates and increase productivity. When employees feel connected to a company, they feel as though co-workers have become like family members and thus naturally want to try harder to keep the company going and help it grow. The study also highlighted the importance of Architects working from their residences as it is easier and cheaper to operate as a balanced lifestyle that offers an opportunity for comfort in the home and good working conditions with official efficiency can be achieved and maintained. The office design should be such that communal interaction is encouraged so as to create strong bonds amongst the intending Architects that will be the major subject of future architectural practice partnerships. This will help to strengthen the chord of Architectural practices in the country and create a spirit of family among Architects. The study concludes that the in the home-office, workplace relationship enhances efficiency; hence, quality project delivery in construction industry in the developing Nations, Nigeria inclusive. The study recommends that the Home Office should be designed as a whole entity, incorporating a smooth blend of both the home and office features without making them seem segregated but a whole unit. Also, the office design should be such that communal interaction is encouraged so as to create strong bonds amongst the intending Architects who will be the major subject of future architectural practice partnerships. This will help to strengthen Architectural practices in the country and create a spirit of family among Architects.

\section{References}

Abdulkarim, M. (2002). Architectural Design Jury on Trial: The Paradigm Studio Project Zaria School in Journal of the Association of Architectural Educators in Nigeria (ARCHEES) 2:2 Pp 12-17

Arayela, O. (2001). Introspection into Forty Years of Architectural Practice in Nigeria (1960-2000): The Way Forward in Nkwogu, U. O. (Ed). Architects and Architecture in Nigeria. Akure: Shalom

Publishers. Pp 91-107.

Amaratunga, D. and Baldry, D. (1998). Appraising the Total Performance of Higher Education Buildings: A Participatory Approach Towards a Knowledge Based System in Construction .Building Research Conference 1998 Proceedings (COBRA), 2nd-3rd September 1998, Oxford Brookes University. Pp 117.

Andrew, P. (2017). Ten Good Reasons Why You Should Live in an Intentional Community (And a Few Reasons Why We Don't). Available at https://www.alliaceforcamphll.com/10-good-reasons-why-you-shouldlive-in-an-intentional-community-and-a-few-reasons-why-we-dont, accessed $15^{\text {th }}$ March 2018.

Architects Registration Council of Nigeria (ARCON), (2013). Register of Architectural firms.

Becker, F. D. (1990). The Total Workplace: Facilities Management and the Elastic Organization. New York: Van Nostrand Reinhold.

Bernard, H. R. (2000). Social Research Methods: Qualitative and Quantitative Approaches. Thousand Oaks, CA: Sage.

Brill, M., S Margulis and Konar, E. (1985). Using office design to increase productivity. Buffalo, New York. Workplace Design and Productivity.

Businessdictionary.com (2018) in http://businessdictionary.com/home office, accessed $5^{\text {th }}$ June2018.

Carlopio, J. R. and Gardner, D. (1992). Direct and Interactive Effect of the Physical Work on Attitudes; Environment and Behaviour Journal, 24 (5), pp. 579-601.

Chauhan, A. (1994). The Quest for Humane Architecture in a Sustainable Living Environment, Paper presented at the International symposium on Appropriateness of Means, hosted by Hausder Architecture, Graz, Austria.

DYG, Inc. (2001). The New Workplace: Attitudes and Expectations of a New Generation. Prepared for Knoll, Inc. and CB Richard Ellis, Inc.

Elmahadi M. A., M. M. Tahir, M. Surat, N. M Tawil, I. M. S. Usman, (2011), Effective Office Environment Architecture: Finding Ingenious Ideas in a Home to Stimulate the Office Environment, The 2nd International Building Control Conference 2011, and Pp 382.

Fay Sweet (1999). Space: Reshaping Your Home for the Way You Want to Live. Conran Octopus Limited. 2-4 
Heron Quays, London.

Foundersguide.com, 2018. http://foundersguide.com/rental office, accessed $5^{\text {th }}$ June 2018. General Services Administration Journal, (2006). Productivity and the Workplace: Featuring the Productivity Payback Model.

Herman Hertzberger, (2005). Lessons for Students in Architecture. Rotterdam.

Hubblehq.com, (2018). http://hubblehq.com/virtual_office, accessed $5^{\text {th } J u n e ~} 2018$.

Leedy, P. D., (1997). Practical Research Planning and Design (6th Edition). New Jersey Prentice Hall

Lockard, E. S., (2006). Habitation in space: the relationship between aesthetics \& dwelling. San Jose, California.

Martinez, V. (2007). Architecture for Space Habitats: Role of Architectural Design in Planning Artificial Environment for Long Time Manned Space Missions. Faculty of Architecture, Technical University Darmstadt, Germany.

Nigerian Institute of Architects (NIA), (2017). Number of registered Architects in Nigeria www.nia.ng.

Ojo, O.I. and Olawale, S.O. (2014). Assessment of weather variability impact on Cassava Yield in South Western Nigeria, LAUTECH Journal of Engineering and Technology, 8(2) 169-175, Nigeria, ISSN: 1597-0000.

Oladiti, A. A., Adeoye, D. O. and Ajibade S. (2017). Maxwell Fry and Jane Drew Partners; he Contributions of British Architects to Built Environment in Colonial Nigeria, 1946-1959.

Oldham, G. (1988). Effect of Changes in Work Space Partitions and Spatial Density on Employee Reactions: A Quasi experiment; Journal of Applied Psychology. 73(2), pp. 253-258.

Olurin, T. (2003). Gender Participation and the Environmental Planning and Management

Process: A Case Study of Water Supply in Bodija Market, Ibadan, Nigeria.

$(\mathrm{EPM})$

Journal of Nigerian Institute of Town Planners, Vol. XVI, pp.1-17.

Sagada, M.L. (2002). Architectural Education and Practice in Nigeria: Reflections on the Contemporary Situation in Association of Architectural Educators in Nigeria $\quad$ (AARCHES)

Journal. 2:1 Pp $21-25$

Salleh, A. G. (2008). Neighbourhood factors in private low-cost housing in Malaysia, 32, Habitat International (2008) Pp 485-493.

Sunoo, B. P. (2000). Redesign for a better work environment. Workforce, HR Trends and Tools for Business Results.

Teicu, A. (2018). 30 Creative Home Office Ideas: Working from Home in Style.

Thompson, A. A., Gamble, J. E., and Strickland, A. J., (2004). Strategy- Winning in the Marketplace. McGrawHill Irwin, New York

Torbica, M. Z. and Stroh, R. C., (1999). An Assessment Model for Quality Performance Control in Residential Construction. Journal of Construction Education, 4(3), 332-340

Ukoha, M. O. and Beamish, J. O., (1997). Assessment of Residents' Satisfaction with Public Housing in Abuja, Nigeria. Habitat International, 21(4) (1997), Pp. 445-460

Waziri, S. G. and Osunkunle, A, (2010). Travails of the Polytechnic Architectural Technologist in Nigeria. Journal of Research in Education and Society, Vol. 1, pp. 104-110.

Wineman, J. D (1986), Behavioral Issues in Office Design, New York: Van Nastrand Reinhold. 